\title{
情報と知識
}

\section{Information and Knowledge}

\author{
安永尚志 \\ Hisashi YASUNAGA
}

人間文化研究機構

National Institute for the Humanities

干105-0011 東京都港区芝公園3-1-1

yasunaga@nihu.jp

\section{1 祝う}

情報知識学会の 20 周年をお祝い申し 上げます。言うまでもなく，この間の 社会全般における情報技術の進展とそ の受容は凄まじいものであった。本会 は，基礎から応用に至る諸課題に時機 を失うことなく取組み，多くの成果を あげてきた。各種の活動を通じて，多 方面へなし得た貢献は高く評価される ものである.とりわけ，SGML やXMLの 啓蒙普及活動並びに研究開発活動は, 情報技術分野における先導的な活動で あり，高い評価はもとより，果たした 役割は特筆される。

当然であるが，本会の果たしてきた 役割と成果は，会員諸氏の努力以外の 何ものでもない.

ところで，本会のこれからを眺めた ときに，少々不安も抱く。裾野は広い が規模が小さい点である（会員数 300 名程で推移）。人文社会科学から理工 学全般に及ぶことが，最大の特徵であ り強みでもあるが，個々の専門領域が 小さい。したがって，個別領域での成
果をあげ，先導性を確保することは一 般に難しい。言わば，専門領域での人 不足である。

そこで, 分野横断的な課題で勝負と いうことになろうか。これは，大きな メリットであり，本会の今後をも示唆 する。言換えれば，異分野間のコラボ レーションである。例えば，最近はよ く文理融合と言われるが，融合による 新たなパラダイムの発見と推進である。 実際に，このような観点を裏付ける成 果も多い。本会が評価され，期待され るところではないだろうか。つまり， 本会以外には対応できる組織はそれ程 多くないと言える。チャンスなのであ る.

なお，蛇足ながら，規模の問題は本 会運営にとっては大きな課題でもある。

\section{2 情報知識を考える}

ここで，少し話題を転ずる.

新たに問うまでもなく，本会は情報 と知識に関わる学会である。しかしな がら，「情報」と「知識」の個々を対 象とする学会かと言うと，単純にはそ 
うとも言えないようにも思える。それ では，複合した「情報知識」という新 たな命題に関わる学会かというと, こ れも断定はできないようにも思える。 未だに判然としないが，少し考えてみ たい。ただし，極めて個人的な見解か も知れない.

まず，本会の諸々の広報を調べてみ た.

「情報」と「知識」であるが，これ らが実は明確に定義されていないよう だ。本会の出版物やホームページをみ ても，情報や知識そのものについては 触れられていない。用語としての意味, 定義，あるいは語源などが未定のよう である。また，相互の関連も明確では ない.

本会のホームページの活動内容の概 要の中で，本会の業務の 1 つに「デー タ・知識・情報の本質に関わる理論, その応用課題などに関する研究交流の 場の提供」とある。情報や知識は，既 存の概念として先験的に与えられ，使 われている。なお，情報や知識は，全 く当り前の用語で殊更に定義する必要 はないのかも知れない.

ここでは，あえて 20 周年であること から，これからの 10 年，20 年をみて， 情報とは何か，知識とは何か，また情 報知識とは何かという初心を整理して おいてもよいように思う。

さて，他分野などではどうだろうか. 情報を冠する学問分野や学協会などは 多く，これら分野で独自のとらわれ方 がされている。ただ，やはり通念とし ての情報や知識という用語が前提とな っていて，本質的な定義は余り明確で
はないように思われる。

\section{3 情報知識を調ベる}

少し調べてみる。ここでは，知識の 源泉は情報であると考える。「情報」 とは何かを問うものとする（以下，便 宜上命題という）。

人間文化研究機構 $[1]$ にある人文科学 における研究資源共有化システムを使 う。何か知識が得られないだろうか。 共有化対象データベースは，2008 年 9 月現在で，国立歴史民俗博物館，国文 学研究資料館, 国際日本文化研究セン タ一，総合地球環境学研究所，国立民 族学博物館の 5 機関で（以下，それぞ れ歴博，国文研，日文研，地球研，民 博という）が持つ，104 種である.

また，これらは 6 種類のカテゴリに 大別されている。所蔵資料目録，本 文・フルテキスト，画像・映像・音響, 所蔵図書 - 杂倠誌目録, 研究文献目録, および事項・ファクト（以下，適宜略 記する）である。

「情報」と「知識」の語源からみて みよう。統合検索システムの全項目検 索（any）で「情報」を入れてみると， 33 種のデータベース（以下，DB）がヒ ットした.レコード数では 20,278 件で ある。内訳は，歴博 13DB 中 1, 382 件， 国文研 11DB 中 3, 728 件, 日文研 3DB 中 35 件，地球研 $2 \mathrm{DB}$ 中 397 件，民博 4DB 中 14,736 件である.

一方，カテゴリ別では，資料目録 9 $\mathrm{DB}$ 中 1,370 件，フルテキスト $1 \mathrm{DB}$ 中 8 件，画像 DB はヒット無し，図書等目録 $5 \mathrm{DB}$ 中 10,625 件, 文献目録 $10 \mathrm{DB}$ 中 8,237 件，ファクト 8DB 中 38 件である. 
検索結果 33DB を通覧してみると誠に 興味深い.大半の $25 \mathrm{DB}$ が目録などの 2 次情報系 DB, 残り 8DB が事項などの 0 次情報または 1 次情報系 DB である。検 索結果 2 万レコード余を全て精查した わけではないが，「情報」の語源に関 わるレコードは得られなかった。ただ し，ファクト系 8DB 中 38 レコードには， 「情報」の用例がいくつかある。これ については後述する。

人文科学における情報の概念を探す 試みは，これらの情報源からは得られ そうもない。当り前ではあるが，これ が分った。

何故か. 理由はいくつか考えられる.

1 つは，これらのデータベースは人 文科学分野の一般的学術用語や概念を 規定していない。所蔵資料などに関わ るデータベースを除いて，大半が研究 機関などに所属する研究者が個々の専 門領域で独自に構築した専門データベ ースである。つまり，この命題に解を 与えるデータベースは，この研究資源 共有化データベース群にはないことに なる.

すなおち，まだまだデータベースは 不足している。翻って, 生涯教育や教 育研究に活用できるおよび活用すべき データベースとしては, 質量共に圧倒 的に不足している。理由は，これらを 作る諸々の環境が未整備なことに尽き る。例えば，作っても評価されないな ども大きな要因の 1 つ.

2 つ目は, メタデータにあるかも知 れない。

この統合検索システムでは，各デー タベースの項目を DCMES (Dublin Core
Metadata Element Set) に基づき，マ ッピングし構築されている[2]. その全 項目（any）では，恐らくタイトル，主 題, 内容記述項目辺りのキーワードか らヒットしたケースと考えられる。つ まり，この命題の意図する事項として のヒットかどうかを推定することは難 しい.

そこで，絞り込みを行う。そのため の検索項目は 6 種類用意されている. ここでは，ファクト系として「人・ 物・時・所」検索を使う。メタデータ として，Dublin Core を基に，人，物， 時, 所の 4 項目にマッピングされてい る。その「物・事」項目に，「情報」 を入れる。なお，他の検索項目は， 「名称・作者・主題」, 「詳細」, 「Dublin Core」，「時空間」がある。 検索結果は，18DB，898 件に絞られ た.ファクト系 $\mathrm{DB}$ も, $6 \mathrm{DB}$ 中 10 件と なった。

この統合検索システムでは原データ ベースに辿り着ける。例えば，土偶 DB (歴博) 中 1 件ヒットした. 原データ ベースの内容は，関連資料としての掲

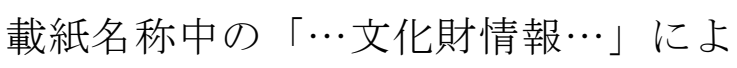
るものであった。また，近代文献情報 DB（国文研）中 1 件ヒットした。明治 期の広告書「情史抄」中の記事である。 1879 年（明治 12 年） 4 月 14 日の東京 日々新聞の広告記事で, $「 \cdots \cdots \cdot . \cdot$ 情報 ……という用例がある。残念ながら， 記事の全文ではないので詳細は不明で あるが，現在のところ「情報」という 用語が使われた最初期の事例でもある （研究資源共有化システムにおける）。 さて，ヒットしたファクト系データ 
ベース 18DB のうち残りの 12DB 中 888 件は，文献資料などの目録である。夕 イトル中に情報という語を含むケース である。例えば，日文研の「日本研 究」DB では, タイトル「……西洋舶来 の書籍情報と徳川日本……」などが典 型例である。また，国文研の「日本古 典籍総合目録」DB では，11 件のヒット があるが，例えば「下田米艦情報書 （安政元年）」や「京都江戸諸国事情 報知録（元治元年）」は面白い。いず れも統一書名であり, 現在の名称付与 かも知れない. とくに, 後者のヒット は情報と言う語のヒットではないが， 知的な興味が湧く例だ。

ついで，参考のために書誌的検索で ある「名称・作者・主題」検索の結果 を示しておく，題目などに「情報」が あるものは，18DB，6,293 件あった。 内訳は, 歴博 7DB 中 933 件, 国文研 $4 \mathrm{DB}$ 中 1,215 件, 日文研 $2 \mathrm{DB}$ 中 5 件, 地球研 2DB 中 199 件, 民博 3DB 中 3, 941 件である。

この結果にはこれ以上立入らないが， 全項目検索の約 3 分の 1 に絞られてい る。

\section{4 これから}

たいへん残念であるが，上記いずれ のデータベースも簡単な索引的な解説 はあるものの，原資料や原データその ものをもっていない.したがって，こ の命題のような問合せには完全には答 えられない。そのような深みのある検 索技術（例えば，DB 連携の強化，横断 検索よりも縦断検索など）の整備が強 く望まれるところである。
これらのデータベースでは，明治期 以前のレコード中に情報という語はヒ ットしない。確かに, 情報は使われて いないようだ。つまり，無かったと考 えられる。

情報は，よく知られているように， 明治初期に Information の訳語として 作られた。本来軍事用語である。「状 報」なども書かれ，当初は諜報の意味 で使われた。この語が現在の意味でい つ頃からどのように使われてきたかを 知ることは興味深い。用例探しも含め, 探求は今後の課題としたい.

参考のため, 「知識」と「情報知 識」の検索結果を示しておく. 全項目 検索で，前者は 23DB，2,837 件ヒット し，後者は $3 \mathrm{DB} ， 5$ 件ヒットした。主と して，雑誌名などによる。

人間文化研究機構の研究資源共有化 システムを使って，どこまで知識を得 ることができるか試みをやってみたが， 検索とその結果の分析はまだまだ不完 全である。希望としては，データベー スの充実，とくに事実データベースが 要る。百科事典的な事項や原典テキス ト，テキストデータなどの充実が肝要 であろう。

\section{参考文献}

[1] 人間文化研究機構の統合検索シス テム : http://www.nihu.jp/

[2] 人間文化研究機構 : NIHU DCメ夕 データマッピング規則他，2008.3

[3] 安永尚志 : 巻頭言「知識の源泉 は，. .」, 情報知識学会誌，18，1, pp.1-2, 2008.2 